\title{
Haemophilia A: carrier detection and prenatal diagnosis by linkage analysis using DNA polymorphism
}

\author{
E G D TUDDENHAM,* ElEANOR GOLDMAN, $\dagger$ A McGRAW,* P B A KERNOFF $\dagger$
}

From the *Haemostatis Research Group, Clinical Research Centre, Harrow, Middlesex, and the $\dagger$ Haemophilia Centre, Royal Free Hospital, London

SUMMARY Restriction fragment length polymorphisms (RFLPs) within or close to the factor VIII locus are very useful for genetic linkage analysis. Such RFLPs allow a mutant allele to be tracked in a family, segregating haemophilia $A$ even when, as is usually the case, the precise mutation causing failure to synthesise factor VIII is unknown. To date two markers tightly linked to the factor VIII locus have been described, one of which is highly polymorphic and therefore informative in most kindreds. A significant crossover rate, however, does not make diagnosis absolute. Three intragenic RFLPs have been defined, which, taken together, are informative in about $70 \%$ of women, providing virtually deterministic genetic diagnosis.

Diagnosis of the carrier state is an urgent clinical problem in families with a known case of haemophilia A. For every affected male, on average eight female relatives will be found who have a greater or lesser genetic risk of carrying the mutant allele. Risk assessment was based until recently on pedigree analysis combined with factor VIII and Von Willebrand factor antigen assays. ${ }^{1}$ At best, about $85 \%$ accuracy of discrimination from the phenotype assays was obtained. As a result many females at relatively low risk opted for definitive antenatal diagnosis by means of factor VIII bioassay or antigen assay of fetoscopic blood sample taken in the second trimester. ${ }^{2}$ The introduction of linkage analysis based on the use of intragenic DNA probes and linked DNA markers has greatly improved definitive diagnosis. ${ }^{3}$ In this paper we describe the DNA probes available for diagnosis of haemophilia A and give examples of their use in families studied over the past two years.

\section{Material and methods}

Families with at least one confirmed case of haemophilia A were referred for genetic counselling to the Haemophilia Centre, Royal Free Hospital, by physicians from the United Kingdom and world wide. Local residents attended in person for counselling and to give blood samples. Some blood and chorion biopsy samples were taken by the referring centre and shipped as whole blood or tissue frozen on dry ice.

\section{SEPARATION OF DNA}

Blood anticoagulated with edetic acid in standard haematology sample tubes was frozen and stored at $-40^{\circ} \mathrm{C}$ until processed. The choice of anticoagulant is dictated by the fact that some restriction enzymes, including XbaI, work poorly or not at all on heparinised samples. No deterioration of DNA over time or after shipment on dry ice from Australia to the United Kingdom was noted. DNA was separated as described $^{45}$ and stored at $-20^{\circ} \mathrm{C}$ until analysed.

\section{DNA PROBES}

DX13 is a fragment of the $\mathrm{X}$ chromosome isolated from an $\mathrm{X}$ genomic library ${ }^{6}$ that has been shown to be linked to haemophilia $A^{7}$ and to the factor VIII gene. ${ }^{8}$ The restriction fragment length polymorphism (RFLP) is detected with BglII.

St14 is a similar fragment derived from the same library 9 and shown to be linked to haemophilia $\mathrm{A}^{10}$ and to the factor VIII gene. ${ }^{8}$ This locus is highly polymorphic with 10 alleles detectable using TaqI.

Factor VIII exon 17,18 This is a genomic Stu I/Sca I fragment that detects a Bc1I RFLP in the adjacent intron $18 .^{8}$ Fig 1 shows the location of this polymorphism.

Factor VIII intron 22 Two probes (designated a 


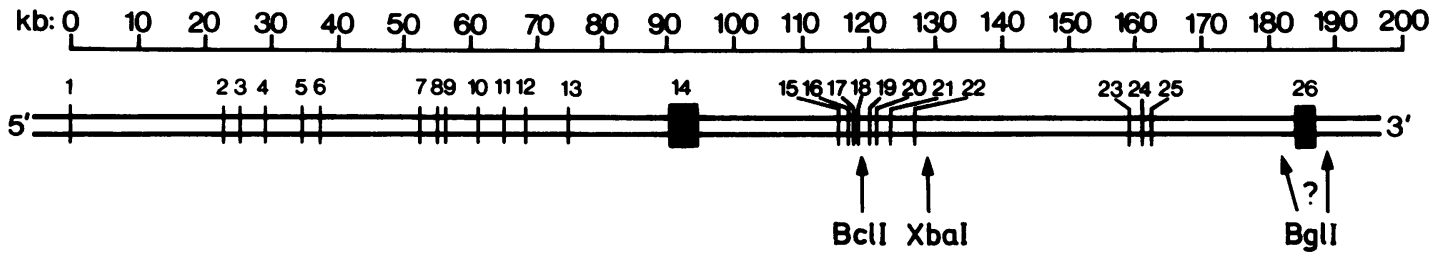

\section{Restriction fragment length polymorphismsin factor VIII}

Fig 1 Approximate location of DNA polymorphisms detectable by restriction enzymes as indicated in factor VIII gene. Solid bars; exons numbered 1 to $26^{16}$, open bars; introns. Precise position of $3^{\prime}$ polymorphic Bgll site has not been mapped.

and b) detect an XbaI polymorphism in intron 22 (fig 1). ${ }^{11}$

Factor VIII 3' A fragment from the $3^{\prime}$ end of factor VIII cDNA that detects a Bg1I polymorphic site. The precise location has not been mapped (fig 1). ${ }^{12}$

\section{DNA MANIPULATION}

Probes were gel purified or separated on $\mathrm{CsCl}_{2}$ gradient by standard methods ${ }^{13}$ and labelled with $\left[\mathrm{d}-{ }^{32} \mathrm{P}\right] \mathrm{dCTP}$ by calf thymus DNA priming. ${ }^{14}$ Southern blotting ${ }^{15}$ was performed after digestion of DNA from a patient with appropriate restriction enzymes.

\section{Results}

The reported incidence of the alleles for intragenic and linked RFLP's varies somewhat according to population and sample size. Table 1 gives percentages based on our own series of mainly northern European ancestry. The largest discrepancy was the frequency of alleles at the factor VIII $3^{\prime} \mathrm{Bg} 1 \mathrm{I}$ site $^{12}$ between European and AfroCaribbean patients. In Europeans about $80 \%$ of $X$ chromosomes have this site-thet is, $5 \mathrm{~kb}$ allele detected-in blacks the frequency is $74 \%$, giving a higher expected heterozygosity rate for females. The cumulative heterozygosity for the three intragenic RFLPs was not additive due to linkage disequilibrium: the time elapsed from the mutation events responsible for the DNA variations was not long enough to allow sufficient meiotic crossovers to randomise the distribution of alleles on all chromosomes.

Table 2 gives haplotypes for $\mathrm{BclI}$ and $\mathrm{XbaI}$. The haplotype $-1+$ (large fragment/small fragment) was rare or absent. This means that women homozygous for $\mathrm{BclI}-$ are not informative for $\mathrm{XbaI}$ either because they will be homozygous for $\mathrm{XbaI}-$. Fortunately, BclI + is the common allele, and such homozygous women $(60 \%)$ have a $37.5 \%(2 \times 0.75 \times 0.25$ $\times 100$ ) chance of being heterozygous for XbaI. Table 3 gives the haplotypes for $\mathrm{BclI}$ and $\mathrm{Bg} 1 \mathrm{I}$. The chance of being heterozygous for both is reduced as the com mon allele $\mathrm{BclI}+$ is associated with the common allele $\mathrm{Bg} 1 \mathrm{I}+$. Only those rare females who are homozygous for BclI $+(4 \%)$ can get additional information from BglI.

The net effect of these imbalances is that about $70 \%$ of European females are informative-that is,

Table 2 Factor VIII Bc1I-XbaI haplotypes

\begin{tabular}{|c|c|c|c|}
\hline \multicolumn{2}{|c|}{ Haplotype } & \multirow{2}{*}{$\begin{array}{l}\text { No of } \\
\text { chromosomes }\end{array}$} & \multirow{2}{*}{$\begin{array}{l}\text { Per cent of } \\
\text { chromosomes }\end{array}$} \\
\hline$B c I I$ & XbaI & & \\
\hline $\begin{array}{l}0.8 \\
0.8 \\
1 \cdot 1 \\
1 \cdot 1\end{array}$ & $\begin{array}{l}4.8(\text { or } 1.4) \\
6.2 \\
4.8 \text { (or } 1.4) \\
6.2\end{array}$ & $\begin{array}{r}45 \\
15 \\
0 \\
14\end{array}$ & $\begin{array}{r}61 \\
20 \\
0 \\
19\end{array}$ \\
\hline
\end{tabular}

Table 1

\begin{tabular}{lllr}
\hline Probe & Enzyme* & Alleles $k b-/+\dagger$ & $\begin{array}{c}\text { Expected } \\
\text { heterozygosity (\%) }\end{array}$ \\
\hline Factor VIII exon 17.18 & Bcl I & $1 \cdot 1 / 0 \cdot 8$ & 34 \\
Factor VIII intron 22 & XbaI & $6 \cdot 2 / 4 \cdot 8$ & $22 / 78$ \\
Factor VIII 3' & BglI & $20 / 5$ & $41 / 59$ \\
DX13 & BglI & $5 \cdot 8 / 2 \cdot 8$ & $20 / 80$ \\
St14 & TaqI & At least 8 & $50 / 50$ \\
\hline
\end{tabular}

*RFLP's are often referred to according to enzyme, such as factor VIII BclI.

$\dagger-$ and + refer to absence or presence of restriction site yielding large or small alleles. 
heterozygous - at one or more polymorphic intragenic sites. These women can be given firm genetic advice based on linkage as the risk of crossover between these markers and a putative mutation must average about $0.1 \%$ per meiosis. The total length of the factor VIII gene is about $200 \mathrm{~kb}$ or $0.2 \mathrm{cM} .^{16}$ The maximum distance from marker to mutation (fig 1 ) is $130 \mathrm{~kb}$ or about $0 \cdot 1 \mathrm{cM}$, equivalent to a $1 / 1000$ crossover rate per meiosis.

For $30 \%$ of women who are non-informative with intragenic RFLPs we must resort to linked markers. St 14 and DX13 are at a small but important map distance from factor VIII. Table 4 gives crossover rates calculated from data sent to Dr I Peake as part of an ongoing collection of data for the International Society on Thrombosis and Haemostasis. ${ }^{17}$ These rates may be overestimates but most centres now recheck antenatal diagnoses based on linked markers with fetoscopic blood sampling. At least three antenatal diagnoses based on St14 linkage have proved erroneous due to crossover. ${ }^{18} 19$ The risk of error increases cumulatively with genetic distance from "consultand" to affected index case. Despite these drawbacks St14 is a valuable marker as it is so

Table 3 Factor VIII Bc1I-BgII haplotypes in northern European population

\begin{tabular}{lccl}
\hline Bcl I & Bgl I & $\begin{array}{l}\text { No of } \\
\text { chromosomes }\end{array}$ & $\begin{array}{l}\text { Per cent of } \\
\text { chromosomes }\end{array}$ \\
\hline 0.8 & 5 & 29 & 66 \\
0.8 & 20 & 0 & 0 \\
$1 \cdot 1$ & 5 & 5 & 11 \\
$1 \cdot 1$ & 20 & 10 & 23 \\
\hline
\end{tabular}

Table 4 Factor VIII linkage (May 1986)

\begin{tabular}{llll}
\hline & Meiosis & Crossovers & Per cent \\
\hline DX 13/VIII intron 18 & 154 & 7 & 4.5 \\
St14/VIII intron 18 & 133 & 6 & 4.5 \\
\hline
\end{tabular}

polymorphic that more than $90 \%$ of females are informative. It has the additional benefit of helping to confirm or exclude paternity.

DX13 was the first linked marker to be discovered and is widely used. It is not very informative compared with St14 and is also subject to crossover error. ${ }^{20}$ As several crossovers have affected both St 14 and DX13 they are most likely on the same side of the factor VIII locus, which is unfortunate as no additional confidence is gained by combining them.

\section{Case histories}

In the family shown in fig 2 two sisters $\left(\mathrm{III}_{2}\right.$ and $\left.\mathrm{III}_{3}\right)$ have a $50 \%$ chance of carriership on pedigree. Based on the factor VIII BclI alleles, II $_{2}$ is informative with the 0.8 allele being associated with haemophilia $\mathrm{A}$ in her father $\left(\mathrm{I}_{1}\right)$ and son $\left(\mathrm{III}_{3}\right)$. Therefore $\mathrm{III}_{2}$ cannot be a carrier, whereas $\mathrm{III}_{3}$ is a carrier. This result is confirmed by the DX13 alleles. If $\mathrm{III}_{3}$ requires antenatal diagnosis in future, the factor VIII BclI polymorphism could not be used as she is homozygous for the $0.8 \mathrm{~kb}$ allele. DX13. Bg1II could be used as she is

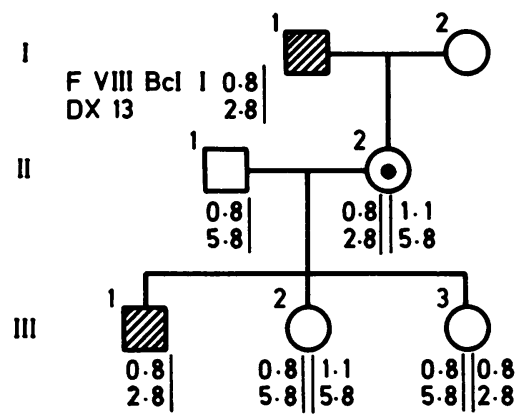

Fig 2 Family segregating haemophilia A. $\mathrm{II}_{2}$ and $\mathrm{III}_{3}$ request carrier determination. $\square$ normal male; $\bigcirc$ female; haemophilic male; $\odot$ obligate carrier. $0 \cdot 1,1 \cdot 1$, RFL alleles in $k b$.

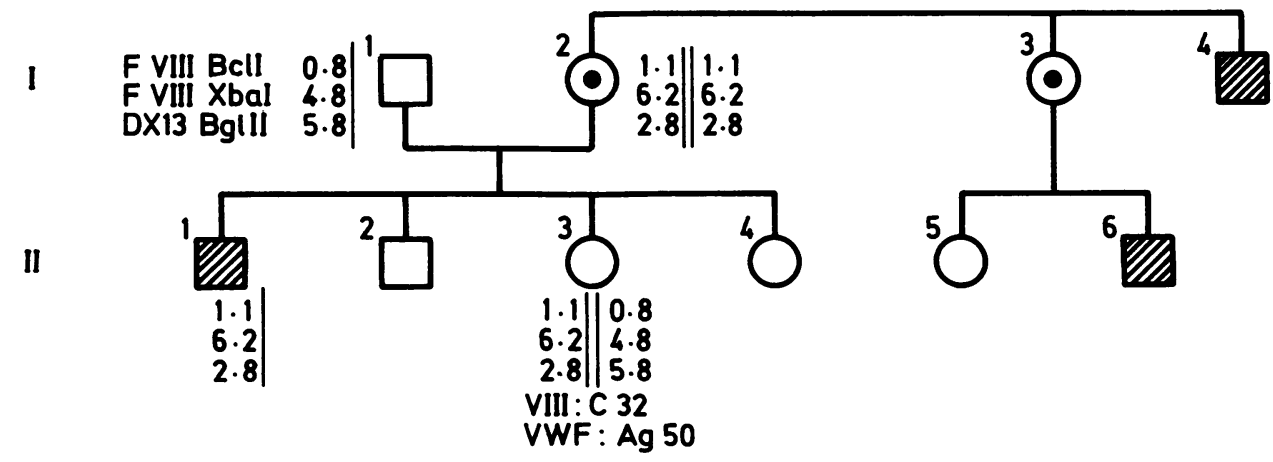

Fig $3 \square$ normal male; $\bigcirc$ female; haemophilic male; $\odot$ obligate carrier. VIII:C factor VIII clotting activity; VWF:Ag Von Willebrand factor antigen assayed in plasma from "consultand" $\mathrm{II}_{3}$. 


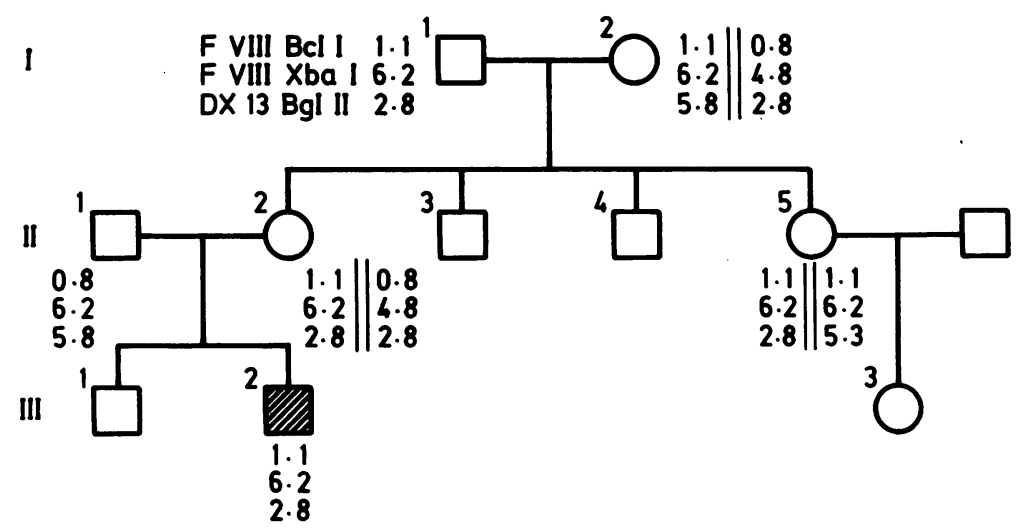

Fig $4 \square$ normal male; $\bigcirc$ female; haemophilic male; $\odot$ obligate carrier. Kindred with sporadic case of haemophilia $A$.

heterozygous, haemophilia A being associated with the $2.8 \mathrm{~kb}$ allele in this kindred. In that case the possibility of crossover must be considered, giving about $4 \%$ error risk for each fetus tested.

The family shown in fig 3 has three affected males $\left(I_{4}, I_{1}\right.$, and $\left.I I_{6}\right)$ and two obligate carriers $\left(I_{2}\right.$ and $\left.I_{3}\right)$. $\mathrm{II}_{3}$ requires carrier determination. Unfortunately, her mother $\left(\mathbf{I}_{\mathbf{2}}\right)$ is homozygous for all three RFLPs tested. The phenotype tests for $\mathrm{II}_{3}$, however, show a very high probability $(200: 1)$ that she is a carrier. She can

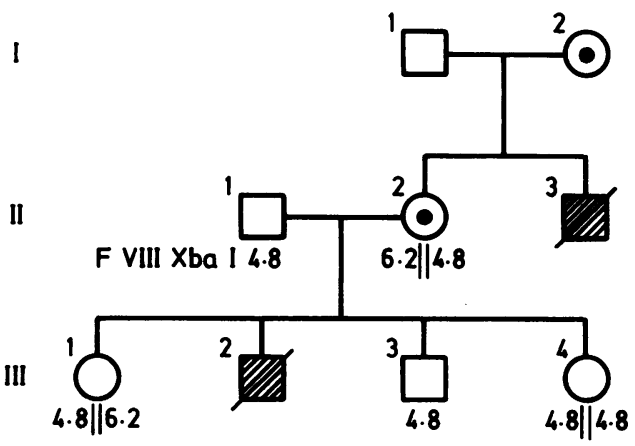

Fig $5 \square$ normal male; $\bigcirc$ female; $\odot$ obligate carrier. deceased haemophiliac patient.

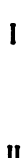

II

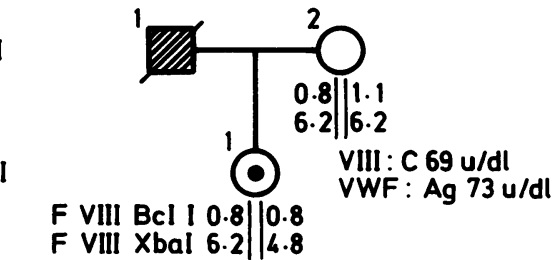

Fig 6 female; deceased haemophilic male; $\odot$ obligate carrier. Analysis for assessment of prenatal diagnosis potential. therefore be counselled on that basis and can have first trimester fetal diagnosis using either the factor VIII BclI or the factor VIII XbaI RFLPs. This case shows the importance of maintaining the phenotype assays (VIII:c and VWF:Ag) as combining information of phenotype and linkage enhances diagnostic potential.

The families in which a single case of haemophilia has occurred at time of consultation (so called spo radic cases) present a different problem-that o determining the level of the mutation, which can be presumed to be of recent origin. Fig 4 illustrates the? power of linkage analysis in such a kindred. A single haemophiliac $\mathrm{III}_{2}$ has the haplotype $1 \cdot 1 / 6 \cdot 2 / 2 \cdot 8$. This is identical with the haplotype of one $\mathrm{X}$ chromosome of his aunt $\mathrm{II}_{5}$ who was the "consultand." This X chromosome, however, must have come from the haemophiliac's normal grandfather $I_{1}$. Therefore a new mutation had occurred either at spermatogenesis from $\mathrm{I}_{1}$ or at oogenesis from $\mathrm{II}_{2}$. In both cases $\mathrm{II}_{5}$ is excluded from carriership. Further information about the status of $\mathrm{II}_{2}$ could be obtained from phenotype analysis or by testing the haplotype of III $_{1}$.

Even in families with no living haemophiliac, linkage analysis is often helpful provided that the diagnosis of the deceased patients was definitive. Fig 5 shows such a family: although $\mathrm{II}_{3}$ and $\mathrm{III}_{2}$ had died, the survival of a normal male $\mathrm{III}_{3}$ enabled predictions to be made from his two sisters $\mathrm{III}_{1}$ and $\mathrm{III}_{4}$ who have a $50 \%$ chance of carriership on pedigree. Clearly the $6.2 \mathrm{~kb}$ allele must be associated with haemophilia. Therefore $\mathrm{III}_{1}$ is a carrier and $\mathrm{III}_{4}$ is not.

In the family shown in fig 6 the "consultand's" father $I_{1}$ had died years ago in Zimbabwe and no other affected relatives were available. A blood sample was flown over to us from $\mathrm{I}_{\mathbf{2}}$ (her mother in South Africa), and by comparing haplotypes it can be inferred that the haemophilic $\mathrm{X}$ chromosome bears 
the $4.8 \mathrm{~kb}$ allele. As $\mathrm{II}_{1}$ is heterozygous for this RFLP she can be offered antenatal diagnosis.

The family shown in fig 7 combine the problems addressed in the two preceding cases with a requirement for antenatal diagnosis of a male fetus $(\diamond)$. Comparison of alleles of $\mathrm{I}_{2}$ and $\mathrm{II}_{2}$ showed that $\mathrm{II}_{2}$ had inherited the $1.1 \mathrm{~kb}$ allele from her haemophilic father (the phenotype results merely confirm that she is an obligate carrier of haemophilia $\mathbf{A}$ ). A chorion biopsy specimen obtained at eight weeks' gestation from III 1 was shown to be male on karyotype. Fetal DNA was extracted ${ }^{5}$ and shown to bear the 0.8 allele. The pregnancy was therefore allowed to continue as the fetus would be normal.

In fig 8 the analysis was performed to help an obligate carrier $\left(\mathrm{III}_{2}\right)$ in future pregnancies. A haemophilic fetus $\left(\mathrm{IV}_{1}\right)$ was diagnosed by fetoscopic

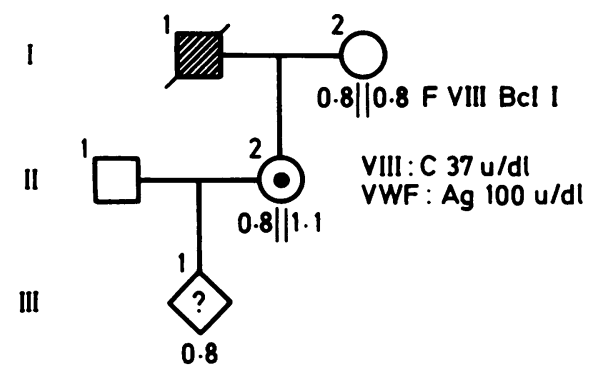

Fig 7 Male fetus $\diamond$. Antenatal diagnosis by DNA analysis despite non-availability of affected relative. blood sampling at 18 weeks and terminated. The patient was non-informative for factor VIII BclI but informative for St14TaqI. The allele number 4 segregates with haemophilia in this family and therefore can be used for antenatal diagnosis, provided a predicted normal male at 18 weeks' gestation is checked by blood sample in case of error due to crossover.

The kindred analysed in fig 9 shows the benefit of using two independent intragenic markers. The consultand $\left(\mathrm{III}_{3}\right)$ was pregnant when she requested diagnosis. A haemophilic uncle $\left(\mathrm{II}_{7}\right)$ was available for

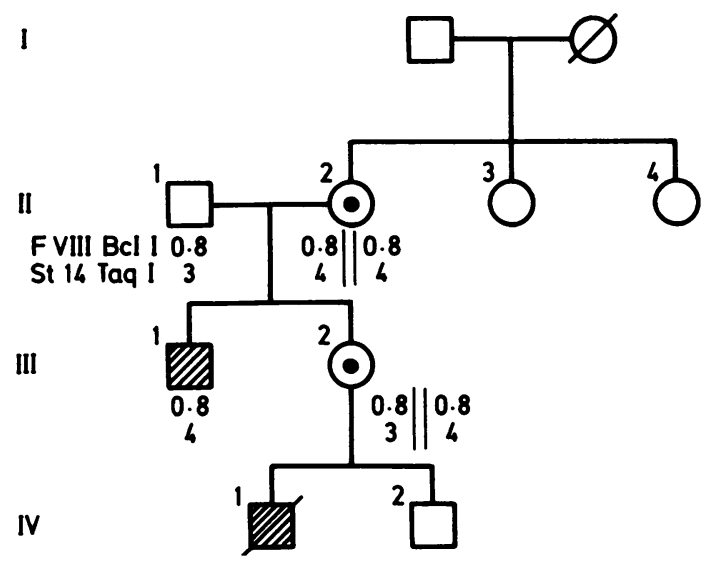

Fig 8 Use of St 14 TaqI RFLP. Intragenic marker non-informative.

Severe haemophilia A

Linkage analysis using two intragenic and one linked probe

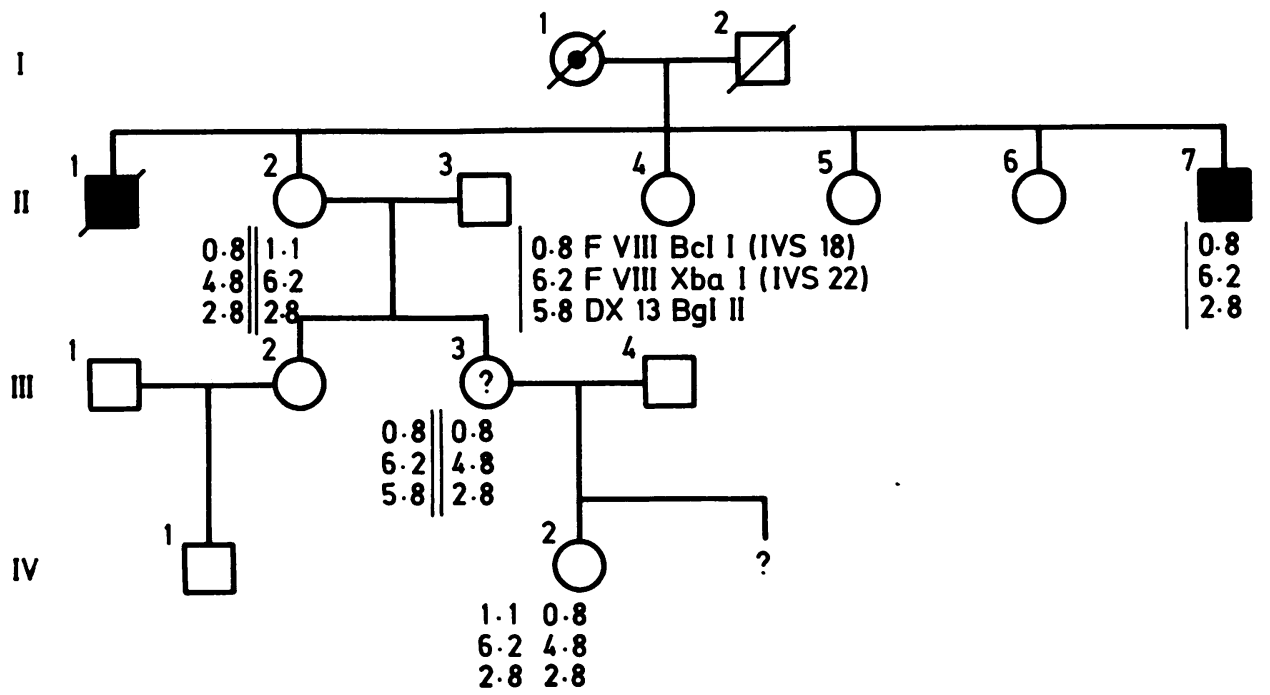

Fig 9 ? Early conceptus, sex not determined. Illustrates exclusion of carriership requiring information from two intragenic RFLP's. 
testing but both grandparents $\left(I_{1}\right.$ and $\left.I_{2}\right)$ were deceased. The phase assignment for $\mathrm{III}_{3}$ was based on her father's haplotype. It was clear that the haplotypes for $\mathrm{II}_{2}$ were such that she could not have inherited the haemophilic $X$ chromosome from $I_{1}$. Therefore $\mathrm{III}_{3}$ is not a carrier and the pregnancy was allowed to continue undisturbed by any sampling.

\section{Discussion}

Availability of intragenic and linked RFLPs for genetic diagnosis of haemophilia A has greatly enhanced our ability to establish definitively carrier status. It is now also possible to perform antenatal diagnosis by linkage analysis using DNA extracted from chorion villus tissue as early as eight weeks' gestation. Several problems remain. As yet available intragenic markers are informative in only $70 \%$ of women. There is a need to identify more RFLPs within and flanking the factor VIII gene. To date, only about $15 \%$ of the gene has been screened for polymorphism, ${ }^{811}$ and it is highly likely more remain to be discovered. As families are often incomplete and some haemophiliacs die young it is essential to retain the phenotype assays, as pointed out by Graham et al. ${ }^{21}$

Certain difficulties of linkage analysis are inherent and can only be contained by vigilance and attention to detail, bearing in mind that paternity may not always be as stated. Table 5 lists some of these problems. In addition, the costs of analyses entailing DNA manipulation are high. Against these costs should be set the considerable improvement in the genetic counselling service to potential carriers, and in the long

\section{Table 5 Some problems of linkage analysis}

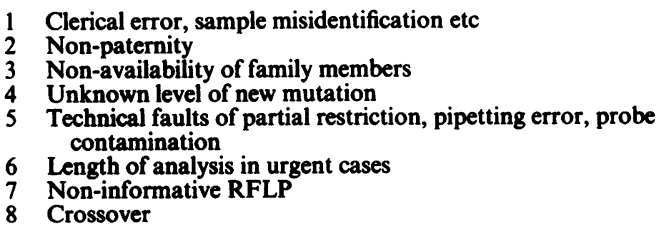

Table 6 Economics of severe haemophilia care and prevention per patient per year (f)

\section{Care:}

Medical and social services

Factor concentrate, 35000 units at $15 p$ per unit

Lifetime cost assuming life expectancy of 65 years

United Kingdom annual cost

$\begin{array}{r}600 \\ 5250 \\ 373750 \\ 11500000 \\ \hline\end{array}$

Prevention:

No of patients born with severe haemophilia in United Kingdom

Preventable (not sporadic) cases

Lifetime cost $=$ potential saving

50
33
$£ 12300000$

run the massive savings of preventing haemophilia (table 6). The projected lifetime savings from efficient prevention in one year would exceed the annual United Kingdom outlay on all living patients. Can we afford not to offer this service as widely as possible?

Gene probes were provided by Dr Richard Lawn of Genentech Inc, or supplied by the authors of the papers listed in the references.

\section{References}

1 Akhmetali MA, Aldorf LM, Alexanents S, et al. Methods for the detection of haemophilia carriers: a memorandum. Bull WHO 1977;55:675.

2 Mibashan RS, Rodeck CH, Thumpston JK, et al. Plasma assay of fetal factor VIIIc and IX for prenatal diagnosis of haemophilia. Lancet 1979;i:1309-11.

3 Wright AF. DNA analysis in human disease. J Clin Pathol 1986;39:1281-95.

4 Bell GI, Kavam JH, Rutter WJ. Polymorphic DNA regions adjacent to the $5^{\prime}$ end of the human insulin gene. Proc Natl Acad Sci USA 1981;78:5759-63.

5 Williamson R, Eskdale J, Coleman DV, Niazi M, Loeffler FE, Modell BM. Direct gene analysis of chorionic villi: a possible technique for first-trimester antenatal diagnosis of haemoglobinopathies. Lancet 1981;ii:1125-7.

6 Davies KE, Young BD, Elles RG, Hill ME, Williamson RO Cloning of a representative genomic library of the human chromosome after sorting by flow cytometry. Nature 1981;293:374-6.

7 Harper K, Winter RM, Pembrey ME, Hartley D, Davies KE Tuddenham EGD. A clinically useful DNA probe closely linked to haemophilia A. Lancet 1984;ii:6-8.

8 Gitschier J, Drayna D, Tuddenham EGD, White RL, Lawn RM. Genetic mapping and diagnosis of haemophilia $A$ achieved through a Bcl I polymorphism in the factor VIII gene. Nature 1985;314:738-40.

9 Oberle I, Drayna D, Camerino G, White R, Mandel J-L. The telomeric region of the human $X$ chromosome long arm: Presence of a highly polymorphic DNA marker and analysis of recombination frequency. Proc Natl Acad Sci USA 1985;82:2824-8.

10 Oberle I, Camerino G, Heilig R, et al. Genetic screening for Haemophilia A (Classic haemophilia) with a polymorphic DNA probe. $N$ Engl $J$ Med 1985;312:682-6.

11 Wion KL, Tuddenham EGD, Lawn RM. A new polymorphism in the factor VIII gene for prenatal diagnosis of haemophilia $\mathbf{A}$. Nucleic Acids Res 1986;14:4535-42.

12 Antonarakis SE, Waber PG, Kittur SD, et al. Haemophilia A. Detection of molecular defects and of carriers by DNA analysis. $N$ Engl J Med 1985;313:842-8.

13 Maniatis T, Fritsch EF, Sambrook J. Molecular cloning. A laboratory manual. New York: Cold Spring Harbor Laboratory, 1982.

14 Taylor JM, Illmensee R, Summer J. Efficient transcription of RNA into DNA by avian sarcoma virus polymerase. Biochim Biophys Acta 1976;442:324-30.

15 Southern EM. Detection of specific sequences among DNA fragments separated by gel electrophoresis. J Mol Biol 1975;98:503-18.

16 Gitschier J, Wood WI, Goralka T, et al. Characterization of the human factor VIII gene. Nature 1984;312:326-30.

17 Peake IR, Bloom AL. Recombination between genes and closely linked polymorphisms. Lancet 1986;i:1335. 
18 Driscoll MC, Miller CH, Goldberg JD. Aledort LM, Hoyer LW, Golbus MS. Recombination between Factor VIII:c gene and St14 locus. Lancet 1986;ii:279.

19 Lehesjoki A-E, de la Chapelle A, Rasi V. Haemophilia A: two recombinations detected with probe St14. Lancet 1986;ii:280.

20 Winter RM, Harper K, Goldman E, et al. First trimester prenatal diagnosis and detection of carriers of haemophilia $A$ using the linked DNA probe DX13. Br Med J 1985;291:765-9.
21 Graham JB, Green PP, McGraw RA, Davis LM. Application of molecular genetics to prenatal diagnosis and carrier detection in the haemophilias: some limitations. Blood 1985;66:759-64.

Requests for reprints to: Dr EGD Tuddenham, Haemostasis Research Group, Clinical Research Centre, Watford Road, Harrow, Middlesex HAl 3HJ, England. 